\title{
Identification of alcohol preference relevant genes in QTL on mouse chromosome 2
}

Lishi Wang ${ }^{1}$, Yan Jiao ${ }^{1}$, Griffin Gibson ${ }^{1}$, Xiaoyun Liu¹, Yue Huang ${ }^{1}$, Beth Bennett ${ }^{2}$, Kristin Hamre ${ }^{3}$, Robert Williams ${ }^{3}$, Weikuan $\mathrm{Gu}^{1 *}$

From 10 ${ }^{\text {th }}$ Annual UT-ORNL-KBRIN Bioinformatics Summit 2011

Memphis, TN, USA. 1-3 April 2011

\section{Background}

Previously, a quantitative trait loci (QTL) for alcohol preference on chromosome 2 in a C57BL/6IBG (B6) background has been identified. The overlap of two of interval specific congenic recombinant strains (ISCRS) strains reduced the QTL interval into a $3.4 \mathrm{mbp}$ region.

\section{Results}

By using the keyword alcohol, we identified a total of 39 genetic elements in the region between markers D2Mit56 and D2Mit10. Among these genetic elements, we found seven with potential function in alcohol preference (Table 1). We then examined the SNPs, insertions and deletions, and gene expression levels of those seven genes.

\section{Conclusions}

Our current data suggest that the Atf 2 and Titin genes are potentially the most alcohol relevant genes. However, further experiments and examination are still needed to confirm their candidacy. Several other candidate genes are also in the process of being identified.

\footnotetext{
Acknowledgments

Support for this research is partially from the NIAAA (1R01 AA016342). NIH, the Veterans Administration Medical Center, and DNA Discovery Core, University of Tennessee, Memphis, TN.

\section{Author details}

${ }^{1}$ Department of Orthopedic Surgery - Campbell Clinic and Pathology, University of Tennessee Health Science Center, Memphis, TN, 38163, USA. ${ }^{2}$ Department of Pharmacology, University of Colorado Denver, Aurora, CO, 80045-0508, USA. ${ }^{3}$ Department of Anatomy and Neurobiology, University of Tennessee Health Science Center, Memphis, TN, 38163, USA.
}

Table 1 Candidate genes for alcohol preference on Chr 2.

\begin{tabular}{|c|c|c|c|c|c|}
\hline $\begin{array}{l}\text { ENSEMBL } \\
\text { ACCESSION }\end{array}$ & SYMBOL & FULL NAME & SNPS & INSERTIONS & DELETIONS \\
\hline ENSMUSG00000027104 & ATF2 & ACTIVATING TRANSCRIPTION FACTOR2 & 3 & & \\
\hline ENSMUSG00000027109 & SP3 & TRANS-ACTING TRANSCRIPTION FACTOR3 & $1(\mathrm{G} / \mathrm{A})$ & & AT(72784944) \\
\hline ENSMUSG00000006494 & PDK1 & PYRUVATE DEHYDROGENASE KINASE, ISOENZYME 1 & & & $-\mathrm{T}(71718212)$ \\
\hline ENSMUSG00000009207 & LNP & LIMB AND NEURAL PATTERNS & 9 & 6 & $\overline{\mathrm{TA}}(74365654)$ \\
\hline ENSMUSG00000027107 & CHRNA1 & CHOLINERGIC RECEPTOR, NICOTINIC, ALPHAPOLYPEPTIDE1 & & & \\
\hline ENSMUSG00000018770 & ATP5G3 & $\begin{array}{l}\text { ATP SYNTHASE, H+ TRANSPORTING, MITOCHONDRIAL FO COMPLEX, } \\
\text { SUBUNIT C, (SUBUNIT 9), ISOFORM } 3\end{array}$ & & & \\
\hline ENSMUSG00000051747 & TTN & CONNECTIN & 1 & & \\
\hline
\end{tabular}

\footnotetext{
* Correspondence: wgu@uthsc.edu

'Department of Orthopedic Surgery - Campbell Clinic and Pathology,

University of Tennessee Health Science Center, Memphis, TN, 38163, USA

Full list of author information is available at the end of the article
}

() Biomed Central

(c) 2011 Wang et al; licensee BioMed Central Ltd. This is an open access article distributed under the terms of the Creative Commons Attribution License (http://creativecommons.org/licenses/by/2.0), which permits unrestricted use, distribution, and reproduction in any medium, provided the original work is properly cited. 
doi:10.1186/1471-2105-12-S7-A2

Cite this article as: Wang et al:: Identification of alcohol preference relevant genes in QTL on mouse chromosome 2. BMC Bioinformatics 2011 12(Suppl 7):A2.

Submit your next manuscript to BioMed Central and take full advantage of:

- Convenient online submission

- Thorough peer review

- No space constraints or color figure charges

- Immediate publication on acceptance

- Inclusion in PubMed, CAS, Scopus and Google Scholar

- Research which is freely available for redistribution 